\title{
Diagnosis of study habits in engineering students in material innovation
}

\section{Diagnóstico de hábitos de estudio en estudiantes de ingeniería en innovación de materiales}

\author{
SESENTO, Leticia’ \& LUCIO, Rodolfo"” \\ 'Colegio Primitivo y Nacional de San Nicolás de Hidalgo, Mexico. \\ "Universidad Michoacana de San Nicolás de Hidalgo, Faculty of Veterinary Medicine and Zootechnics, Mexico.
}

ID $1^{\text {st }}$ Author: Leticia, Sesento / ORC ID: 0000-0002-6456058X, Researcher ID Thomson: S-6997-2018, CVU CONACYT ID: 449302

ID $1^{\text {st }}$ Co-author: Rodolfo, Lucio / ORC ID: 0000-0002-0535-3652, Researcher ID Thomson: X-2391-2018, CVU CONACYT ID: 947303

DOI: $10.35429 / J T E R .2021 .19 .7 .1 .7$

Received January 10, 2021; Accepted June 30, 2021

\begin{abstract}
The beginning of a university career is an opportunity that is given to young people when accessing higher education in Mexico, for the student it is hard work and at times it is saturated with difficulties, which manage to resist with motivation, and study habits that help students to finish the university career. The overall objective of this research is to analyze and promote habits to develop the Action Plan Tutorial of the next school year to promote activities that are in line with the interests of students. It is a cross-sectional descriptive investigation through surveys, since variables are not manipulated by naturally targeting phenomena or facts. To carry out this research, a simple sampling was carried out with second and fourth semester students of the Engineering degree in Material Innovation of the UMSNH (Universidad Michoacana de San Nicolás de Hidalgo). Description of the instrument. Study habits test, admits to appreciating and detailing study habits; which can be managed in groups and/or individual, in an average time of 15 minutes, consists of 20 items. With regard to the questioning if, do you study periodically and not just before the exam? $47 \%$ of students refer to only studying from time to time, while $32 \%$ study almost always. Environmental condition factors, study planning, material utilization, content assimilation, and sincerity of study habit scales generally show a low-to-normal moderate utilization level trend. Study habits in their different factors require improving the degree of use.
\end{abstract}

\begin{abstract}
Resumen
El inicio de una carrera universitaria es una oportunidad que se les brinda a los jóvenes al acceder a la educación superior en México, para el estudiante es un trabajo arduo y en momentos está saturado de dificultades, mismas que logran resistirse con motivación, y hábitos de estudio que ayuden a los estudiantes a finalizar la carrera universitaria. La presente investigación tiene como objetivo general analizar y promover los hábitos para elaborar el Plan de Acción Tutorial del siguiente ciclo escolar para promover actividades que sean acorde a los intereses de los estudiantes. Es una investigación descriptiva transversal mediante encuestas, ya que no se manipulan las variables fijándose de forma natural en los fenómenos o hechos. Para realizar la presente investigación se efectuó un muestreo simple estratificado con estudiantes de segundo y cuarto semestre de la carrera de Ingeniería en Innovación de Materiales de la UMSNH (Universidad Michoacana de San Nicolás de Hidalgo). Descripción del instrumento. Test de hábitos de estudio, admite apreciar y detallar los hábitos de estudio; el cual se puede administrar en grupos y/o individual, en un tiempo promedio de 15 minutos, consta de 20 ítems. Con relación al cuestionamiento si, ¿Estudias periódicamente y no sólo antes del examen? $47 \%$ de los estudiantes hacen referencia que solamente estudian de vez en cuanto, mientras $32 \%$ estudia casi siempre. Los factores condiciones ambientales, planificación del estudio, utilización de materiales, asimilación de contenido y sinceridad de las escalas de hábitos de estudios muestran de forma general una tendencia de nivel de utilización de normal bajo a normal moderado. Los hábitos de estudio en sus diferentes factores requieren mejorar el grado de utilización.
\end{abstract}

Hábitos de estudio, Estudiantes, Nivel superior, Ingeniería

Citation: SESENTO, Leticia \& LUCIO, Rodolfo. Diagnosis of study habits in engineering students in material innovation. Journal of Teaching and Educational Research. 2021. 7-19:1-7.

\footnotetext{
* Correspondence to the Author (Email: leticiasesentogarcia@yahoo.com.mx)

$\dagger$ Researcher contributing as first author.
} 


\section{Introduction}

The beginning of a university career is an opportunity that young people are given when accessing higher education in Mexico, for the student it is hard work and at times it is saturated with difficulties, which they manage to resist with motivation, and habits of study that help students to finish the university career. Likewise, the great change from upper secondary education to higher education for certain students is a complex experience, since the work is excessive, the study programs with enormous amounts of content, the number of subjects enrolled, the number of exams, final assignments, tasks, schedules and the family, economic and social context, all these variables can influence the completion of university studies. To develop the present work, a crosssectional descriptive research was carried out, using the survey technique on study habits with 25 items on the liker scale. A simple stratified sampling was carried out with second and fourth semester students.

\section{Development}

Habits are behaviors that individuals assimilate through repetition. There are habits in correspondence with health, food and study, among others. It is important to note that habits benefit without hesitation, the achievement of goals as long as they are worked on appropriately at different stages of life. Habit, from the etymological perspective, is the usual way of being and, by extension, the set of constant skills that, when nature and culture concur, respond to a certain persistence of our reactions and behaviors. The habit is the set of routines and the ways to distinguish, appreciate, conceptualize, resolve and think (Perrenoud, 1996).

\section{Theoretical framework}

Habit is a behavior achieved by reproduction and transformed into an automatic intervention, while memory and inclinations are ways of storing the past. The periods of habit are formation and permanence. The first is described as the acquisition time and the second is the period in which the actions have already been achieved and the actions are formalized in a habitual, easy and involuntary way (Velázquez, 1961).
Study habits are the methods and strategies that a student uses to assimilate knowledge, their ability to prevent entertainment, attention to explicit material and the energies that they formalize throughout the process (Cartagena, 2008).

Authors such as Bajwa, Guijar, Shaheen and Ramzan (2011) indicate that a student is unable to use effective study skills, even if he does not have good habits and they analyze that a subject assimilates very quickly and in depth in correspondence with study habits. At the same time, they insist that effective and efficient learning lies more than memorization of facts, in being aware of where and how to acquire substantive research and the ability to create use of it.

The habits that a student has can be lost, but they can also be increased or recovered (Díaz and García, 2008). The gain of habits demands training, so the change that it involves is not easy work, since it has to be motivated by a higher intention, by the willingness to submit what one wants today to what one will seek later. Study habits are defined as the methodologies and strategies that a student manages to apply in order to cope with a large number of learning contents. The study habit demands enormous amounts of effort, discipline, and dedication. In addition, it is nourished by impulses that manage to be formed by the perspectives and motivations of the student who wants to learn.

Improving the learning and academic performance of students, mainly in higher education, has an essential role in the development process in society. The motivation of the students is decisive, so it is necessary to develop a better scope of the elements of academic motivation; It is feasible that the different social context manages to be one of the aspects that influence motivation and academic self-concept (Isiksal, 2010).

Daily practice shows that the study habit represents an outstanding mechanism for academic success for academic objectivity. It manages to be explicit as the study of methods and forms that facilitate the acquisition of more complex daily knowledge (Téllez, 2005). In this way, study habits concern being related to the peculiarities of the career, and with the explicit objectives of academic work, specifically. 
In the tutoring, a pedagogical correspondence different from that instituted in teaching in front of large groups is developed, in this case the educator takes the role of guide in a relaxed and friendly setting (Latapí, 1998). Research on study habits in students is a principle that fosters spaces for progress aimed at working on the execution of workshops that support students in developing skills and strategies to optimize their study habits, while working with the paths academic to place students in their academic and work projection.

University tutoring is an opportunity to offer orientation and guidance to university students, in such a way that they manage to develop intellectual, cordial, personal and also social levels, which are central to promoting comprehensive training. It is essential to underline that university tutoring channels and activates the relations of university students both in the administrative, educational, organization and service areas; likewise, it allows the intervention of the student in the integral formation.

On the other hand, Amor (2012) mentions that it is essential to reflect that the academic training of the students corresponds to be focused on their learning, but assuming a committed university professor (tutor) of the subjects, which stimulates the motivation of the students and recording the efforts made to correct and achieve innovation and promotion to the tutorial function is an action carried out by university teachers, focusing on the guidance and counseling of students in their subjects.

The benefits of academic college tutoring are as follows:

a) Increase the quality of the educational process through individualized attention to the difficulties that influence the disadvantages of the student's school performance, in order to optimize learning situations, develop values, attitudes, habits and skills that favor the integrity of their professional and human training. b) It strengthens a quality educational practice through better communication between students and teachers, based on the recognition, perspectives and specific problems of students in order to develop options that can have a favorable impact on their academic, private and professional training.

c) Reduces dropout rates and university academic failure.

d) Establish educational environments of familiarity that allow to have a favorable influence on the student's academic performance.

e) It favors to optimize the learning situations of the students, through the study and collective reflection of the training developed in the tutorial process.

University tutoring is an opportunity to provide guidance and guidance to university students, in such a way that they manage to develop intellectually, personally, socially; for development and comprehensive training.

It also favors individualizing the education of the university system. In the teaching process at the university, it allows students to prepare themselves in the maturity of their knowledge and attitudes.

University tutoring moderates and strengthens the relationships of university students, both in the administrative and educational environment, in the organization of services; on the other hand, it allows the active contribution of students.

The objective of this research was to know the study habits in students of the Engineering in Materials Innovation career at UMSNH.

Specific objectives:

Analyze the habits to develop the Tutorial Action Plan for the next school year

Promote activities that are consistent with the interests of students. 


\section{Methodology}

It is a cross-sectional descriptive investigation through surveys, since the variables are not manipulated by looking naturally at the phenomena or facts. To carry out this research, a simple stratified sampling was carried out with second and fourth semester students of the Engineering in Materials Innovation career at UMSNH (Universidad Michoacana de San Nicolás de Hidalgo).

\section{Description of the instrument}

Study habits test admits to appreciate and detail study habits; which can be administered in groups and / or individually, in an average time of 15 minutes, consists of 20 items.

\section{Analysis of results}

The research was carried out with 47 students of both sexes from the Engineering in Materials Innovation career at UMSNH, in the second and fourth semesters; students are from rural, semirural and urban places. From the interior of the republic and the state of Michoacán.

The ages of the students range from 19 to 26 years old. The percentage of students according to gender $32 \%$ female and $68 \%$ male.

Regarding the question if, do you study periodically and not just before the exam?

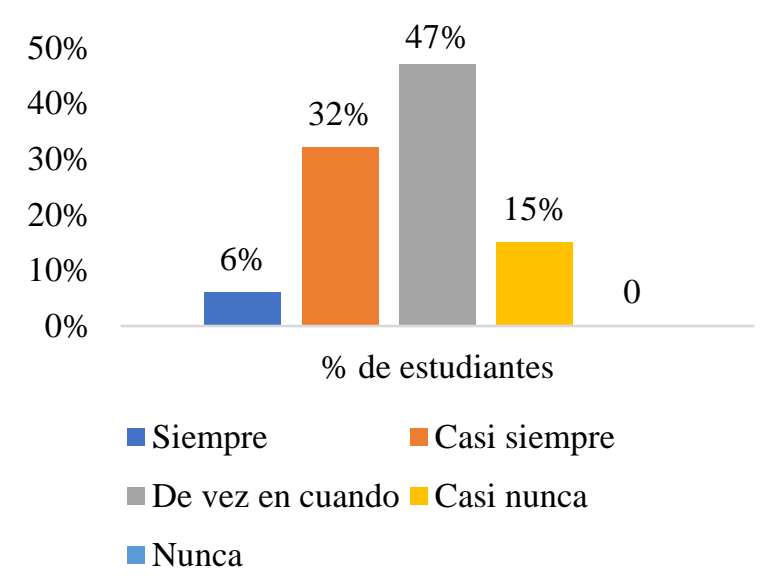

\section{Graphic 1}

$47 \%$ of the students refer that they only study once in a while, while $32 \%$ study almost always.

Regarding the questioning, do you check multimedia objects (TV, Internet, cell phone, etc.) while you study?

ISSN-2444-4952

ECORFAN $^{\circledR}$ Todos los derechos reservados
$38 \%$ of the population mention that from time to time they check multimedia objects, while $32 \%$ check multimedia objects (TV, Internet, cell phone, etc.) from time to time.

Do you sleep 7-8 hours regularly?

$34 \%$ of students almost always sleep between 7 to 8 hours, while $32 \%$ sleep between 7 and 8 hours.

On the other hand, in relation to yes, do you do physical activity regularly?

$28 \%$ of students do physical activities periodically from time to time and $32 \%$ do physical activity all the time.

Do you assume costs of resources and time?

In reference to the question, if you assume costs of resources and time?

$47 \%$ of the students indicated that almost always, 28\% occasionally and 23\% always assumes the resources and time.

Do you procrastinate using other activities as a refuge to avoid facing the study? $36 \%$ of students procrastinate once in a while, $34 \%$ almost never, while $17 \%$ almost always do.

\section{Conclusions}

A diagnosis of study habits with which students enter the degree is essential, this will admit knowing strengths, weaknesses and opportunities. In correspondence to formalize tutorial action programs. In order to strengthen study habits with courses - workshops, prepared by experts from the Faculty of Psychology of the Universidad Michoacana de San Nicolás de Hidalgo.

The results obtained in this research lead to approve the hypothesis that second and fourth semester students do not have sufficient study habits.

Through academic tutorials, a program is proposed that allows students to develop attitudes and aptitudes for study. Discover in a timely manner students with low grades, poor academic performance or with personal problems. In order to invite them to Personal Growth, Life and Career Planning Workshops.

SESENTO, Leticia \& LUCIO, Rodolfo. Diagnosis of study habits in engineering students in material innovation. Journal of Teaching and Educational Research. 2021 
On the other hand, it is important that higher-level students have educational spaces such as study circles and self-learning workshops that facilitate the acquisition and strengthening of appropriate study habits.

It is timely at first that educators guide students in relation to different study techniques, as well as the use of these so that they optimize their time in their studies to achieve an adequate academic result. Also, make talks on planning and organization of time, using study techniques and management of educational resources; by the tutor teachers aimed at students who have inadequate study habits and attitudes.

\section{References}

Ander-Egg.E (2001). Trabajo en equipo. México. Ed. Progreso.

Amor, M (2012). La orientación y la tutoría universitaria como elementos para la calidad y la innovación en la Educación Superior. Modelo de Acción Tutorial (Tesis doctoral) Córdoba, España: Universidad de Córdoba.

Asociación Nacional de Universidades e Instituciones de Educación Superior (ANUIES, 2000, 2001). Programas institucionales de tutoría. Una propuesta de la ANUIES para su organización y funcionamiento en las instituciones de Educación Superior. México. ed. ANUIES.

Ausubel, D. P. \& Robinson, K. G. (1969). Aprendizaje en la escuela. Una introducción a la psicología educativa. New York. ed. Holt, Rinehart y Winston

Bajwa, N., Gujjar, A., Shaheen, G., y Ramzan, M. (2011). A comparative study of the study habits of the students from formal and nonformal systems of education in Pakistan. International Journal of Business \& Social Science, 2(14), consulted of E-Journal database. 175186, http://www.scielo.org.mx/scielo.php?script $=$ sci_nlinks\&ref=5159708\&pid=S0185-

$2760201200030000300004 \& \operatorname{lng}=\mathrm{es}$

Bruner, J.S. (1988). Desarrollo cognitivo y educación. Madrid. Ed. Morata.
Cabrera, A. M. A. y Sánchez, A. W. M. (2004). Hábitos de estudio y rendimiento académico. Tesis de Licenciatura de Psicología. México. ed. Universidad de Guanajuato.

Cartagena, M. (2008). Relación entre la autoeficacia, el rendimiento escolar y los hábitos de estudio de secundaria. Revista Iberoamericana sobre Calidad, Eficacia y Cambio en Educación, vol. 6 (3). http://www.rinace.net/arts/vol6num3/art3.p df, Viewed: April, 2015.

Covey, S. (2009). Los siete hábitos de la gente altamente efectiva. Barcelona. Editorial. Paidós. Díaz, S. y García M. (2008). Escuela de desarrollo de hábitos. Vencer las rutinas para conseguir hábitos directicos saludables. $2^{\mathrm{a}} \mathrm{ed}$. Madrid. ed. Díaz de Santos.

Escalante, L., Escalante, Linzaga, C., y Merlos, M. (2008). Comportamiento de los estudiantes en función a sus hábitos de estudio. Revista electrónica actualidades investigativas en educación, $8 \quad$ (2). $\quad$ pp. 1 15, https://doi.org/10.15517/aie.v17i3.29123

Fernández, F. (1988). Técnicas de estudio en Diccionario de Ciencias de la Educación, Madrid. ed. Santillana.

Furnham, A. (2004). Psicología Organizacional: El comportamiento del individuo en las organizaciones, México. ed. Alfa Omega. Informe Gobierno Federal, solicitud de información 0001100404112011.

García, M., Alvarado, J. y Jiménez, A. (2000). La predicción del rendimiento académico: regresión lineal versus regresión logística. Revista de Psicothema. 12 (3). pp. 248-252, doi: 10.7334/psicothema2016.372

Hernández Sampieri, R., Fernández Collado, C. y Baptista Lucio, P. (2006). Metodología de la investigación. $4^{\mathrm{a}}$ ed. México. ed. Mc Graw Hill. Isiksal, M. (2010). A Comparative Study on Undergraduate Students' Academic Motivation and Academic Self-Concept. The Spanish Journal of Psychology, consultado el 24 de septiembre,

2012 , de: http://redalyc.uaemex.mx/redalyc/src/inicio/ ArtPdfRed.jsp?iCve=17217376005\#,pp.572585,PMID 20977008. 
Kancepolski, J. y Ferrante, A. (2006). El proceso de enseñanza y aprendizaje. Programa de formación docente pedagógica. Madrid. ed. Serie Paltex, OPS/OMS

Kancepolski, J. y Ferrante, A. (2006). El proceso de enseñanza y aprendizaje. Programa de formación docente pedagógica. Madrid. ed. Serie Paltex, OPS/OMS

Latapí, S. P. (1988). La enseñanza tutorial: elementos para una propuesta orientada a elevar la calidad la calidad. En Revista de la Educación Superior, núm. 68, octubre-diciembre.

Márquez, E. (1995). Hábitos de estudio y personalidad. México. ed. Trillas.

Martínez-Otero, V y Torres, L. (2001). Análisis de los hábitos de estudio en una muestra de estudiantes universitarios. Revista Iberoamericana de educación 32 (2).

Mira y López, E. (1995). Cómo estudiar y cómo aprender. Buenos Aires. ed. Kapeluz.

Mena, A (2009) ¿Qué es enseñar y qué es aprender?. Editorial Santillana. Ecuador.

Núñez, C. y Sánchez, J. (1991). Hábitos de estudio y rendimiento en EGB y BUP. Un estudio comparativo. Revista Complutense de Educación, Vol. 2 (1). Universidad Complutense,

Madrid. http://revistas.ucm.es/index.php/RCED /article/view/RCED9191130043A/18163,

Viewed: May, 2014.

Oñate, C. (2001). La tutoría en la Universidad. Instituto de Ciencias de la Educación, Madrid. ed. UPM.

Montes de Oca, R, N (2011) Estrategias docentes y métodos de enseñanza-aprendizaje en la Educación Superior, México. Humanidades Médicas es la publicación científica del Centro de Desarrollo de las Ciencias Sociales y Humanísticas en Salud (CENDECSA) Vol .II http://humanidadesmedicas.sld.cu/index.php/h $\mathrm{m} /$ article/view/127/81

Pavlov, I. (1927). Reflejos del condicionamiento. Londres. ed. Oxford University Press.
Perellón, M. J. (2014). Psicología energética. EFT para el éxito académico. Manual para el manejo de la ansiedad ante los exámenes. Raleigh, North Carolina, United Stats. Ed. Lulu Press Inc.

Perrenoud, P. (1996). La construcción del éxito y del fracaso escolar. $2^{a}$ ed., Madrid. ed. Morata. Piaget, J. (1969). El nacimiento de la inteligencia en el niño. Madrid. ed. Aguilar.

Pozar, F. (2002). Inventario de hábitos de estudio. Madrid. Publicaciones de Psicología aplicada. ed. TEA.

Reyes, S. L. y Obaya, A. (2008). Hábitos de estudios de los alumnos de Ingeniería Agrícola y su impacto en el rendimiento acadobtenido en un curso de Química Básica, En Revista Información Tecnológica, Vol 1(5), Chile. http://www.scielo.cl/pdf/formuniv/v1n5/art05.p df, Retrieved: January, 2012.

Sánchez, C. S. (2002). Diccionario de las Ciencias de la Educación. $18^{\text {va }}$ ed. México. ed. Aula Santillana.

Skinner, B. F. (1954). La ciencia del aprendizaje y el arte de la enseñanza. Harvard educ. Rev., 24 Tapia, Tapia, B. (2000). Apuntes de metodología de la investigación. México. ed. Trillas.

Téllez, L. (2005). Hábitos de estudio de los alumnos de la Carrera de Ingeniero Agrónomo Fitotecnista del CEP-CSAEGR. Tesis de Licenciatura. Colegio Superior. Los hábitos de estudio y motivación para el aprendizaje de los alumnos en tres carreras de Ingeniería Agropecuaria del Estado de Guerreo, Centro de Estudios Profesionales, Cocula, Guerrero, México.

Tinto, V. (1992). El abandono en los estudios superiores. Una nueva perspectiva de las causas de abandono y su tratamiento. Cuadernos de

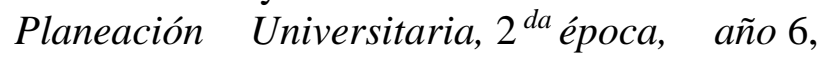
núm. 2, México. ed. UNAM/ANUIES

Tirado, F., Martínez, M., Covarrubias, P., López, M., Quesada, R., Olmos, A., DíazBarriga F. (2010). Psicología educativa para afrontar los desafíos del siglo XXI. México. ed. McGraw Hill. 
Torres, M., Tolosa, I., Urrea, M., Monsalve, A. (2009). Hábitos de estudio vs fracaso académico. En Revista Educación de la Universidad de Costa Rica, Vol. 33, Núm. 2. http://redalyc.uaemex.mx/pdf/440/44012058 002.pdf, Retrieved: January, 2012.

Valdés, G. L. E. (2001). Hábitos de estudio y rendimiento escolar en estudiantes de segundo grado de secundaria. Tesis de licenciatura de Psicología. Toluca. ed. Facultad de Ciencias de la Conducta/ UAEM.

Velázquez, J. (1961). Curso Elemental de Psicología. México. Ed. Selector.

Vidal, L., Gálvez, M. y Reyes, L. (2009). Análisis de hábitos de estudio en alumnos de primer año de Ingeniería Civil Agrícola. En Revista Formación Universitaria, Vol. (2), La Serena, Chile. http://www.scielo.cl/scielo.php?pid=S07 18-50062009000200005\&script=sci_arttext, Retrieved: January, 2012.

Vygotsky, L. (1978). Mente en sociedad. El desarrollo más alto de los procesos psicológicos. Editado por M. Cole, V. JohnSteiner, S. Scribner y E. Souberman. Cambridge. ed. Harvard University Press.

Watson, J. B. (1914). Comportamiento: Una introducción a la Psicología Comparativa. New York. ed. Henry Holt.

Zúñiga, M. C. (1993). Estilos y estrategias de aprendizaje de los alumnos de la Universidad de La Serena y su relación con la percepción del contexto académico. Centro Interuniversitario de Desarrollo-CINDA, Chile. ed. Fondo de Desarrollo del Ministerio de Educación.

Zúñiga, M. C. (1998). Algunos criterios para la formulación de una estrategia integral de docencia en educación superior: una mirada desde la relación enseñanza-aprendizaje. Centro interuniversitario de Desarrollo-CINDA. Chile. ed. Fondo de Desarrollo del Ministerio de Educación. 